to create cell lines from patients with disorders such as Parkinson's disease and diabetes, and use them to screen drugs and examine cell pathology (see page 462).

Nature took the unusual step of soliciting an independent verification of the paper during the process of peer review (see D. S. Cram et al. Nature doi:10.1038/nature06456;2007). This is the first time that Nature has obtained second-party replication ahead of publication. It should not be seen as reflecting a mistrust of scientists in the cloning field or scepticism about this particular research group. Rather, our actions fulfilled a statement in an Editorial (see Nature 439,243 ; 2006) that was conceived in the aftermath of the Hwang affair: "Keeping in mind the principle that extraordinary claims require extraordinary proof, Nature may in rare cases demand it."

The decision was partly pragmatic - the corroborating experiment was straightforward and an expert was willing to do it on a timescale that would not delay publication of the paper. It was also based on history. Past fraud is no reason to submit an entire discipline to unusually tough review, but a history in stem-cell research of difficulties in replication of genuine claims carries some weight. The experiments are tough to do, there are many 'moving parts' in nuclear transfer and, given the importance of the conclusions of this work, it is desirable to be doubly robust in excluding the possibilities that embryos were a result of parthenogenesis, cell-line contamination or sample mishandling. (A blog discussion of peer-review challenges in stem-cell research and the peer-review reports for the paper by
Byrne et al. can be found at Nature Reports Stem Cells; www.nature. com/stemcells.)

So Nature asked a team led by Alan Trounson of Monash University in Victoria, Australia, an expert on human embryonic stem cells, to obtain tissue samples from the donor animals and stem-cell lines, and to test for the origins of the stem cells' nuclear and mitochondrial DNA by genotyping. In successful nuclear transfer, the mitochondrial DNA will come from the oocyte donor and the nuclear DNA from the somaticcell nuclear donor. An Oregon veterinary surgeon, Theodore Hobbs, collected tissue from the
"Researchers should consider maintaining tissue samples, and trying to establish and fulfil requirements that may go beyond the routine." animals, coded it, observed DNA preparation in the authors' lab, and then shipped the samples to a laboratory at University of Southern California, where Monash scientist David Cram conducted the analysis.

Nature will continue to evaluate the need for such validation on a case-by-case basis. Meanwhile, researchers should consider maintaining tissue samples, and trying to establish and fulfil requirements that may go beyond the routine, as Byrne et al. did for their cloning paper. In that way, remarkable scientific developments can remain as free as possible from unwarranted speculation and controversy.

\section{Better late than never}

\section{The decision to make the Leopoldina Germany's national academy of sciences is to be welcomed.}

T he road to a national academy for Germany has been a long and rocky one. Back in 1990, just months after reunification, then science minister Heinz Riesenhuber asked the Leopoldina - the learned society with the longest tradition in the Germanlanguage part of the world - to take on the role. But having just emerged from 40 years of communist quasi-isolation, the leaders of the 355-year-old academy declined to do so.

Seventeen years, two government changes and four science ministers later, Germany finally has a national academy. And it is the Leopoldina that will form its basis (see page 470).

When science minister Annette Schavan, a Christian Democrat like Riesenhuber, announced on 16 November that the Leopoldina should fill this role, it this time accepted the invitation.

Germany's seven regional scientific academies were surprised, and in some cases annoyed, by the decision. The country's Länder (states) have far-reaching autonomy in cultural affairs, which is why designating the national voice in science to a single body has been problematic in the past. As a result, Germany lacks a body that can represent the national opinion on science to the outside world and to German policy-makers in the way that the Royal Society does in Britain, or the National Academies in the United States.

Schavan's move therefore deserves applause. It resolves, by satisfyingly non-bureaucratic means, an issue that had threatened to become buried forever between folders and beneath reports. That it was made by virtual fiat, with little public consultation, doesn't spoil the effect.

Germany will benefit from a national academy that can provide genuinely independent advice on scientific questions. The challenges posed to the federal government by such matters as global warming, genetics and demographic change demand such a mechanism.

The current, fragmented academy landscape doesn't match the needs of a large modern nation such as Germany. Some would have preferred to set up a new body (see Nature 443, 371-372; 2006), but this is not actually necessary. The Leopoldina,
"Germany will benefit from a national academy that can provide genuinely independent advice on scientific questions." formed in 1652 and based in Halle in eastern Germany, demonstrated in communist times its independence and its moral and scientific integrity. It has all it takes to serve as a national academy, and it should take up its work with confidence.

Germany's regional academies should accept the invitation to assist it in its new task, particularly by adding their strengths in the humanities, where the Leopoldina lacks expertise (the academy will be responsible for Wissenschaft, the German word for science that actually embraces the humanities as well as hard science). If the outcome proves to be as solid and deeply rooted in science as is the Leopoldina's reputation, then this decision was worth the 17-year wait. 